\title{
Molecular Characterization Indian Isolates of Pasteurella multocida Isolated from Buffalo and Cattle in India
}

\author{
Archana Yadav ${ }^{1}$, Anita Sharma ${ }^{1}$, Rajesh Kumar ${ }^{2}$, V.D.P. Rao ${ }^{2}$ and M.K. Saxena ${ }^{3}$ \\ ${ }^{1}$ Department of Microbiology, C.B.S.H, ${ }^{2}$ Department of Veterinary Microbiology, C.V.Sc \\ ${ }^{3}$ Animal Biotechnology Centre, Department of Veterinary Physiology and Biochemistry \\ College of Veterinary and Animal Science, G. B. Pant University of Agriculture \&Technology, \\ Pantnagar-263145, India \\ *Corresponding author
}

\section{A B S T R A C T}

Keywords

Pasteurella multocida, palindromic REPPCR

Haemorrhagic Septicaemia

Article Info

Accepted:

15 August 2016

Available Online:

10 September 2016
The applicability of repetitive palindromic sequences based differentiation of Pasteurella multocida serogroup B isolates involved in outbreak of haemorrhagic septesemia (HS) in Tarai region of India was evaluated. Seven isolates of Pasteurella multocida B: 2 were isolated from buffaloes and cattle. These were subjected to phenotypic and genotypic characterization. PCR assays were used for the characterization of these isolates. Repetitive extragenic palindromic REP- PCR and Enterobacterial repetitive intergenic consensus ERIC- PCR differentiated all the seven isolates into six profiles. All the isolates were found genetically distinct from standard Pasteurella multocida strain P52 (Vaccine strain of India).Two isolates shared same profile while all other isolates shown different profiles. This study provides a clear evidence of presence of more than one isolate in single outbreak of HS and also provide indication of high genetic variation among field isolates of Pasteurella and may be the reason of vaccine failure and outbreaks.

\section{Introduction}

Haemorrhagic Septicaemia (HS) is an important disease cattle and buffalo in India. It is by Pasteurella multocida types B: 2, B: 2, 5 and B: 5 and has high mortality rate. Conventional methods of disease diagnosis are time consuming as it requires isolation identification and differentiation through bacteriological techniques. With the advancement of molecular biology Polymerase chain reaction (PCR)-based techniques has been extensively used for detection and differentiation of pathogens (Shivshankar et al., 2001; Saxena et al., 2006; Shivchandra et al., 2006; Saxena et al., 2004, Nagagapa et al., 2007). HSB-PCR (Haemorrhagic Septicaemia serotype B specific PCR) is rapid, specific and highly sensitive, are being employed efficiently for early detection (Towensend et al., 1998) and differentiation of various isolates of $P$. multocida B:2 from single and different outbreaks (Biswas et al., 2004). 
In the present study HS suspected animals were screened using HSB-PCR. Seven isolates were isolated from affected animals (Cattle and Buffalo). These were characterized by using conventional (biochemical, pathogenicity testing, antibiotic analysis) and molecular markers. Two DNA markers were used these were Enterobacterial repetitive intergenic consensus sequence (ERIC) and Repetitive extragenic palindromic sequence (REP) these are repetitive sequences present in family Enterobacteriacae. Out ward primers for these sequences were developed by Verosalovic et al. 1991 and field isolates of Pasteurella multocida were differentiated on basis of copy number and inter sequential distances (Loubinoux et al., 1998; Saxena et al., 2006).

In present study investigations was carried out during an outbreak of haemorrhagic septesemia to study genetic variation among field isolates using conventional and molecular markers with respect to design a strategic control measures.

\section{Materials and Methods}

\section{Screening of samples by HSB-PCR}

\section{Preparation of culture lysate}

Blood samples (5 $\mathrm{ml}$ each) and nasal discharges were collected from affected animals and healthy. Samples were inoculated in $2 \mathrm{ml}$ of BHI broth for $18 \mathrm{hrs}$ at $37^{\circ} \mathrm{C}$. $1.5 \mathrm{ml}$ of $18 \mathrm{hrs}$ growth was subjected for centrifugation. Pellet was resuspended in $100 \mu 1$ sterilized triple distilled water. Then tubes were boiled at $100^{\circ} \mathrm{C}$ for 10 minutes and chilled immediately in ice. The tubs were centrifuged at $5000 \mathrm{rpm}$ for 10 minutes to remove cell debris. $5 \mu l$ of the supernatant was used as template for $25 \mu \mathrm{l}$ of PCR reaction.

\section{HSB-PCR}

PCR was conducted by using KTSP 61 and KTT 72 primers (Towensend et al.1998) for the detection of Pasteurella multocida serotype B. $25 \mu \mathrm{l}$ reaction mixture containing $5 \mu \mathrm{l}$ of lysate, $1 \mathrm{X}$ PCR buffer, $1.5 \mathrm{mM} \mathrm{MgCl} 2,200 \mu \mathrm{M}$ of each of dNTPs, 20 pmol of each primer and $1 \mathrm{U}$ Taq DNA polymerase was prepared. All PCR reagents were procured from MBI-Fermentas .PCR was performed with an initial denaturation step $\left(94^{0} \mathrm{C}\right.$ for $5 \mathrm{~min}$ ) followed by 30 cycles of denaturation $\left(94^{\circ} \mathrm{C}\right.$ for $\left.1 \mathrm{~min}\right)$, annealing $\left(55^{\circ} \mathrm{C}\right.$ for $\left.1 \mathrm{~min}\right)$ and extension $\left(72^{\circ} \mathrm{C}\right.$ for 1 min, with a final) extension at $72^{0} \mathrm{C}$ for 10 $\min$.

Amplified product were separated by agarose gel electrophoresis $(1.5 \%$ agarose in $1 \mathrm{X} \mathrm{TAE}$ ) at $5 \mathrm{~V} / \mathrm{cm}$ for $2 \mathrm{~h}$ and stained with ethidium bromide $(0.5 \mu \mathrm{g} / \mathrm{ml})$. DNA fragments were observed by UV transilluminator and images were stored using gel documentation system (AlphaImager 2200 Documentation and Analysis System, Alpha Innotech Corporation, USA).

\section{Isolation of $\boldsymbol{P}$. multocida serotype B from positive samples}

Positive lysates were inoculated in mice by intraperitoneal route. Heart blood was collected from died mice and streaked on plate of blood agar. Isolated single colony was used for methylene blue staining and HSB-PCR.

\section{Biochemical test}

Each isolate was tested for oxidase, indole and catalase tests. Growth of colony was observed on McConkey's agar and on blood agar. All the isolates were tested for fermentation of sugars glucose, fructose, 
maltose, mannitol, sucrose and lactose. The isolates were tested for utilization of citrate, and gelatin.

\section{Antimicrobial sensitivity test}

Isolates were tested for their sensitivity against antimicrobial agents. The antibiograms was determined using a total of eleven different antibiotic discs (amoxycillin, $30 \mu \mathrm{g}$, pefloxacin, $5 \mu \mathrm{g}$, cephalexin, $30 \mu \mathrm{g}$, enrofloxacin, $10 \mu \mathrm{g}$, ciprofloxacin, $30 \mu \mathrm{g}$, streptomycin, $10 \mu \mathrm{g}$, gentamycin, $30 \mu \mathrm{g}$; erythromycin, $15 \mu \mathrm{g}$; oxytetracyclin,30 $\mu \mathrm{g}$, chloramphenicol, 30 $\mu \mathrm{g}$, sulphamithazole, $300 \mu \mathrm{g}$ ) on $\mathrm{BHI}$ agar according to disc diffusion method described by Carter and Subronto (1973).

\section{Differentiation of isolates by ERIC-PCR and REP-PCR}

Genomic DNA of all the isolates was extracted as per the C-Tab method described by Wilson (1987). REP-PCR was performed as per protocol described by Saxena et al., (2006) with some variations. Briefly, $25 \mu 1$ reaction mixture containing $50 \mathrm{ng}$ of genomic DNA and 20pmol of each primer in 1X PCR buffer, $1.5 \mathrm{mM} \mathrm{MgCl}_{2}, 200 \mu \mathrm{M}$ of each of the four dNTPs and $0.5 \mathrm{U}$ Taq polymerase.PCR was performed with an initial denaturation step $\left(94^{0} \mathrm{C}\right.$ for 5 min.)followed by 30 cycles of denaturation $\left(94^{\circ} \mathrm{C}\right.$ for $\left.1 \mathrm{~min}.\right)$, annealing $\left(45^{\circ} \mathrm{C}\right.$ for 2 min.) and extension $\left(72^{\circ} \mathrm{C}\right.$ for 6 min.), with a final extension at $72^{\circ} \mathrm{C}$ for $10 \mathrm{~min}$. Amplicons were loaded on $1.5 \%$ agarose and subjected for electrophoresis at $5 \mathrm{~V} / \mathrm{cm}$ for $2 \mathrm{hrs}$. 100bp ladder was used as size marker. Fingerprints were stored in taggedimage filed (TIF) format with Bio ID software (Vilber Lourmat, Paris, France). Two fingerprints were considered identical if the same number of bands at the same positions were observed.
ERIC-PCR was also conducted as per described by Biswas et al., (2004) with some variations. A reaction mixture of $25 \mu 1$ containing 50ng of genomic DNA and 20pmol of each primer in 1X PCR buffer, $1.5 \mathrm{mM} \mathrm{MgCl} 2,200 \mu \mathrm{mol} / \mathrm{l}$ of each of the 4 dNTPs and 0.5U Taq polymerase.PCR was performed with an initial denaturation step $\left(94^{0} \mathrm{C}\right.$ for $5 \mathrm{~min}$.)followed by 30 cycles of denaturation $\left(94^{0} \mathrm{C}\right.$ for $1 \mathrm{~min}$.), annealing $\left(45^{\circ} \mathrm{C}\right.$ for $2 \mathrm{~min}$.) and extension $\left(72^{\circ} \mathrm{C}\right.$ for 6 min.), with a final extension at $72^{\circ} \mathrm{C}$ for 10 min. Amplicons were loaded on $1.5 \%$ agarose and subjected for electrophoresis at $5 \mathrm{~V} / \mathrm{cm}$ for $2 \mathrm{hrs}$.

\section{Results and Discussion}

\section{Isolation and phenotypic characterization}

A total of seven strains were confirmed by HSB-PCR as $P$. multocida, serotype B these were designated P1, P2, P3, P4, P5, P6 and $\mathrm{P} 7$. All the seven isolates gave amplified products of $\sim 620 \mathrm{bp}$ determining the products specific for HS causing serogroup $\mathrm{B}$ isolates (Figure 1).

The isolated bacterial colonies on blood agar plates were small, glistening, mucoid and dewdrop- like and appeared to be Gramnegative coccobacilli when stained with Gram's stain. Agglutination was produced on serological testing with antiserum raised against whole cell antigen of $P$. multocida $(\mathrm{B}: 2)$.

All of the seven isolates were oxidase and catalase positive and urease negative. No growth was observed on McConkey's agar and were found to be non haemolytic on blood agar. All the isolates fermented glucose, fructose, maltose, mannitol and sucrose, but did not fermented lactose. The isolates were positive for indole test and no reaction was seen with citrate, and gelatin. 


\section{Antimicrobial sensitivity test}

The results indicated that all the isolates exhibited drug resistance against amoxicillin and were sensitive for enrofloxacin followed by pefloxacin, ciprofloxacin, gentamycin, erythromycin, choramphenicol, oxytertracyclin, streptomycin, cephalexin.

In ERIC-PCR, amplified products were observed in all the isolates (Figure 2). However, out of the seven, five profiles were obtained and the products size varied from 128 to 2012. In ERIC type I isolates (P1 and P5) were present. In ERIC type II isolates (P4 and P6) were present. In ERIC type III, IV and V isolates P2, P3 and P7 were present respectively. Band of $488 \mathrm{bp}$ were observed in all seven isolates.

REP-PCR analysis of all the seven isolates revealed five different profiles (Figure 3 ). In REP type I isolates (P2 and P3) were present. In REP type II isolates (P4 and P6) were present. In REP type III, IV and V isolates P1, P5 and P7 were present respectively.

Two bands of sizes 1080 and $784 \mathrm{bp}$ were amplified in all the isolates. These may be Pasteurella-specific loci and can be exploited for the identification of $P$. multocida.
In both ERIC and REP-PCR P52 vaccine strain revealed entirely different profile. ERIC and REP profile data was analyzed using NTSYSpc v2.0 and dendogram was constructed. On combined typing out of seven, six different profiles were observed. P4 and P6 were showing common profile. (Fig. 4) .

In north India the disease assume to be epizootic during rainy season (JuneSeptember) (Khera, 1979) The attempts to isolates a causative agent from various animals resulted in isolation of a few $P$. multocida strain from cattle and buffaloes. Though more than hundred samples were collected but few isolates were isolated. The failure to isolate the organism from many cases could be due to administration of antimicrobial drug prior to sample collection. The isolates could not be differentiated on the basis of conventional methods involving culture, pathogenicity test and biochemical characterization. Earlier similar types of finding were reported from India (Biswas et al., 2004).

Isolates revealed resistance for amoxicillin which is very commonly used in India. Though isolates were found to be sensitive for many other drugs (enrofloxacin) because these are costly and not so routinely used in field cases (Yoshimura et al., 2001).

Table.1 Primers sequences used in the PCR technique for identification and characterization

\begin{tabular}{|c|c|c|c|c|}
\hline $\begin{array}{l}\text { S. } \\
\text { No }\end{array}$ & $\begin{array}{l}\text { Type of } \\
\text { PCR }\end{array}$ & & Sequences of primers used & References \\
\hline 1 & HSB-PCR & $\begin{array}{l}\text { KTT72 } \\
\text { KTSP61 }\end{array}$ & $\begin{array}{l}\text { 5'AGG CTC GTT TGG ATT ATG AAG-3' } \\
\text { 5'ATC CGC TAA CAG ACT CTC-3' }\end{array}$ & $\begin{array}{l}\text { Townsend } \\
\text { et al. (1998) }\end{array}$ \\
\hline 2 & REP PCR & $\begin{array}{l}\text { REP1R 1Dt- } \\
\text { REP2 1Dt- }\end{array}$ & 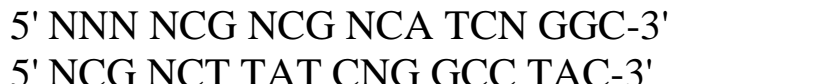 & $\begin{array}{l}\text { Versalovic } \\
\text { et al }(1991)\end{array}$ \\
\hline 3 & ERICPCR & $\begin{array}{l}\text { ERIC 1R- } \\
\text { ERIC2- }\end{array}$ & 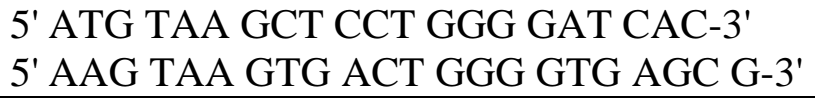 & $\begin{array}{l}\text { Versalovic } \\
\text { et al.(1991) }\end{array}$ \\
\hline
\end{tabular}


Table.2 ERIC PCR profile of field isolates of Pasteurella multocida

\begin{tabular}{|l|l|l|l|l|l|l|l|}
\hline P1 & P2 & P3 & P4 & P5 & P6 & P7 & P52 \\
\hline & & & & & & & 2012 \\
\hline & & & 1860 & & 1860 & & 1860 \\
\hline 931 & & 931 & & 931 & & 931 & 931 \\
\hline 821 & & 821 & 821 & 821 & 821 & & \\
\hline & & 680 & & & & & 680 \\
\hline 488 & 488 & 488 & 488 & 488 & 488 & 488 & 488 \\
\hline 340 & & 340 & 340 & 340 & 340 & 340 & 340 \\
\hline 250 & & 250 & & 250 & & 250 & 250 \\
\hline & & & 170 & & 170 & & \\
\hline & & & & & & 128 & 128 \\
\hline
\end{tabular}

Table.3 REP-PCR profile of field isolates of Pasteurella multocida

\begin{tabular}{|l|l|l|l|l|l|l|l|}
\hline P1 & P2 & P3 & P4 & P5 & P6 & P7 & P52 \\
\hline & & & & & & & 3649 \\
\hline & & & & 2456 & & & \\
\hline 2142 & 2142 & 2142 & & & & & \\
\hline 1580 & 1580 & 1580 & & & & & \\
\hline & & & & & & 1147 & \\
\hline 1080 & 1080 & 1080 & 1080 & 1080 & 1080 & 1080 & 1080 \\
\hline & & & 899 & & 899 & & \\
\hline 784 & 784 & 784 & 784 & 784 & 784 & 784 & 784 \\
\hline & 446 & 446 & & 446 & & & 446 \\
\hline & 300 & 300 & & & & 300 & 300 \\
\hline
\end{tabular}

Table.4 Combined REP-ERIC profiles of isolates of P. multocida

Combined profiles

\begin{tabular}{|l|l|l|l|l|l|l|l|l|l|l|l|l|l|l|l|l|l|l|l|l|}
\hline $\begin{array}{l}\text { Strain } \\
\text { no. }\end{array}$ & a & b & c & d & e & f & g & H & i & J & k & L & m & n & o & P & q & r & s & T \\
\hline P1 & 0 & 0 & 1 & 0 & 0 & 1 & 0 & 1 & 1 & 0 & 1 & 1 & 0 & 1 & 0 & 1 & 0 & 1 & 0 & 0 \\
\hline P2 & 0 & 0 & 1 & 0 & 0 & 1 & 0 & 1 & 0 & 0 & 0 & 1 & 0 & 1 & 1 & 0 & 1 & 0 & 0 & 0 \\
\hline P3 & 0 & 0 & 1 & 0 & 0 & 1 & 0 & 1 & 1 & 0 & 1 & 1 & 1 & 1 & 1 & 1 & 1 & 1 & 0 & 0 \\
\hline P4 & 0 & 0 & 0 & 0 & 1 & 0 & 0 & 1 & 0 & 1 & 1 & 1 & 0 & 1 & 0 & 1 & 0 & 0 & 1 & 0 \\
\hline P5 & 0 & 1 & 0 & 0 & 0 & 0 & 0 & 1 & 1 & 0 & 1 & 1 & 0 & 1 & 1 & 1 & 0 & 1 & 0 & 0 \\
\hline P6 & 0 & 0 & 0 & 0 & 1 & 0 & 0 & 1 & 0 & 1 & 1 & 1 & 0 & 1 & 0 & 1 & 0 & 0 & 1 & 0 \\
\hline P7 & 0 & 0 & 0 & 0 & 0 & 0 & 1 & 1 & 1 & 0 & 0 & 1 & 0 & 1 & 0 & 1 & 1 & 1 & 0 & 1 \\
\hline P52 & 1 & 0 & 0 & 1 & 1 & 0 & 0 & 1 & 1 & 0 & 0 & 1 & 0 & 1 & 1 & 1 & 1 & 1 & 0 & 1 \\
\hline
\end{tabular}

a, 3649 bp; b, 2456 bp; c, 2142 bp; d, 2012 bp; e, 1860 bp; f, 1580 bp; g, 1147 bp; h, 1080 bp; i, 931 bp; j, 899 bp; k, 821 bp; 1, 784 bp; m, 680 bp; n, 488 bp; o,446 bp; p, 340 bp; q, 300 bp; r, $250 \mathrm{bp}$; s, $170 \mathrm{bp}$; t, 128 bp; 0,band present; 1, band absent. 
Fig.1

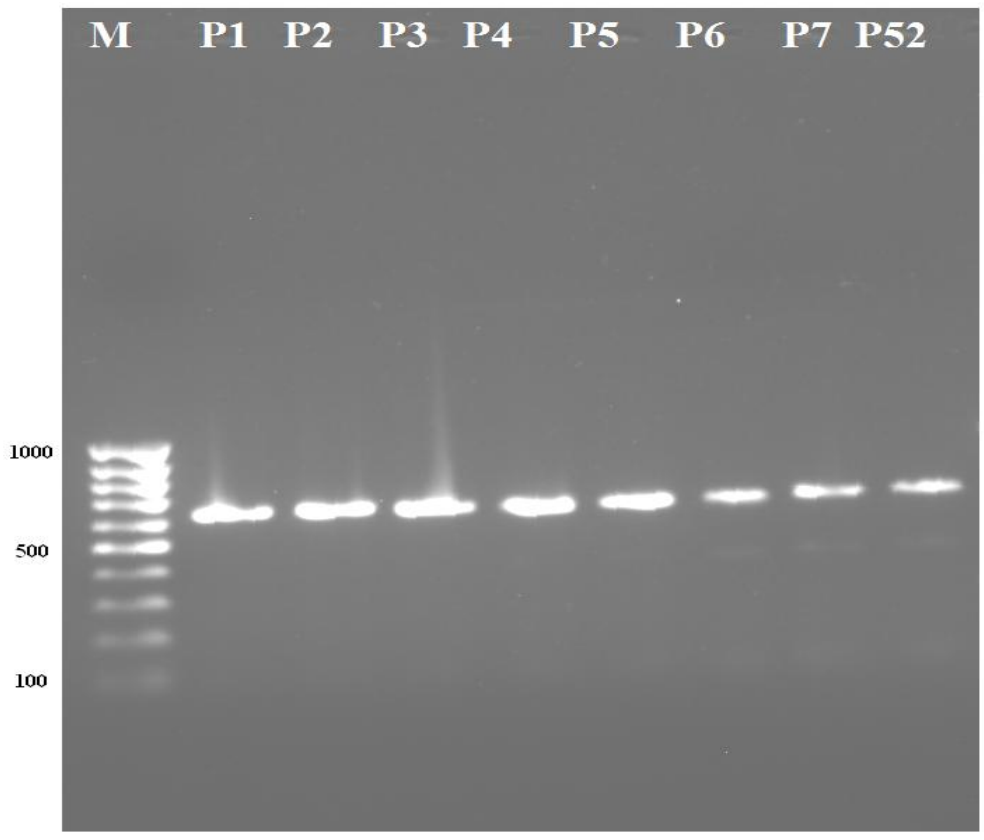

Figure 1. HSB PCR profiles. Lanes: M: Marker, $100 \mathrm{bp}$ ladder; P1: isolate

P1; P2: isolate P2; P3: isolate P3; P4: isolate P4; P5: isolate P5; P6: isolate P6

$\mathrm{P} 7$ : isolate P7; P52: Vaccine strain.

Fig.2

\section{P1 P2.P3 P4 P5 P6 P7 P52}
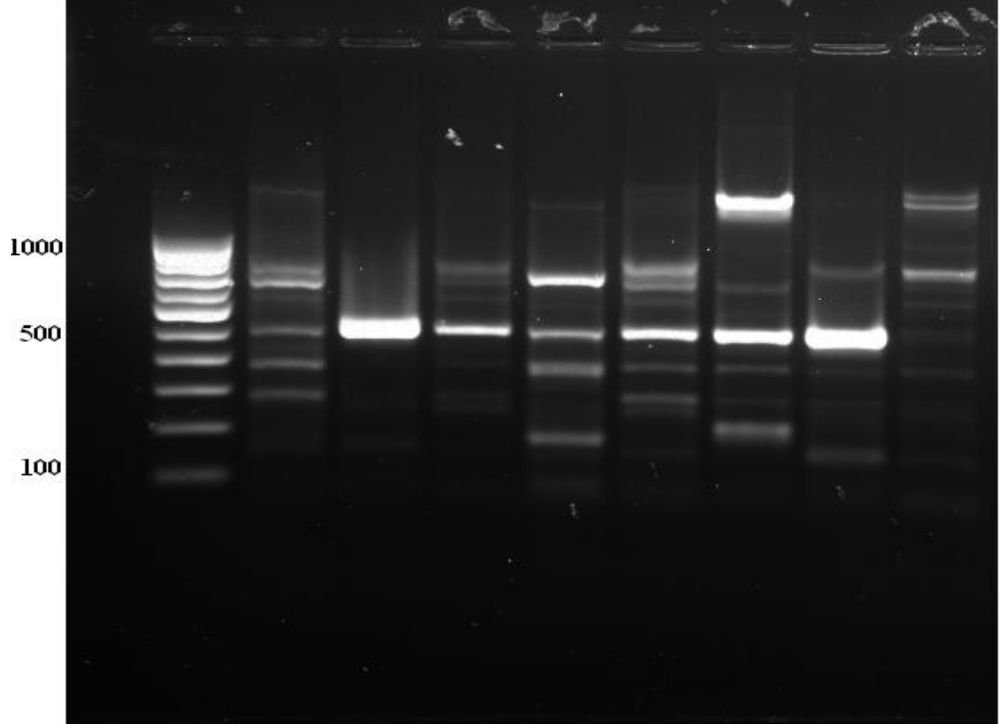

Figure 2. ERIC PCR profiles. Lanes: M: Marker, 100 bp ladder; Pl: isolate $P 1$; $P 2$ : isolate $P 2$; 3 : isolate P3; P4: isolate P4; P5: isolate P5; P6: isolate P6; $P 7$ : isolate $\mathbf{P 7}$; 52 : Vaccine strain. 
Fig.3

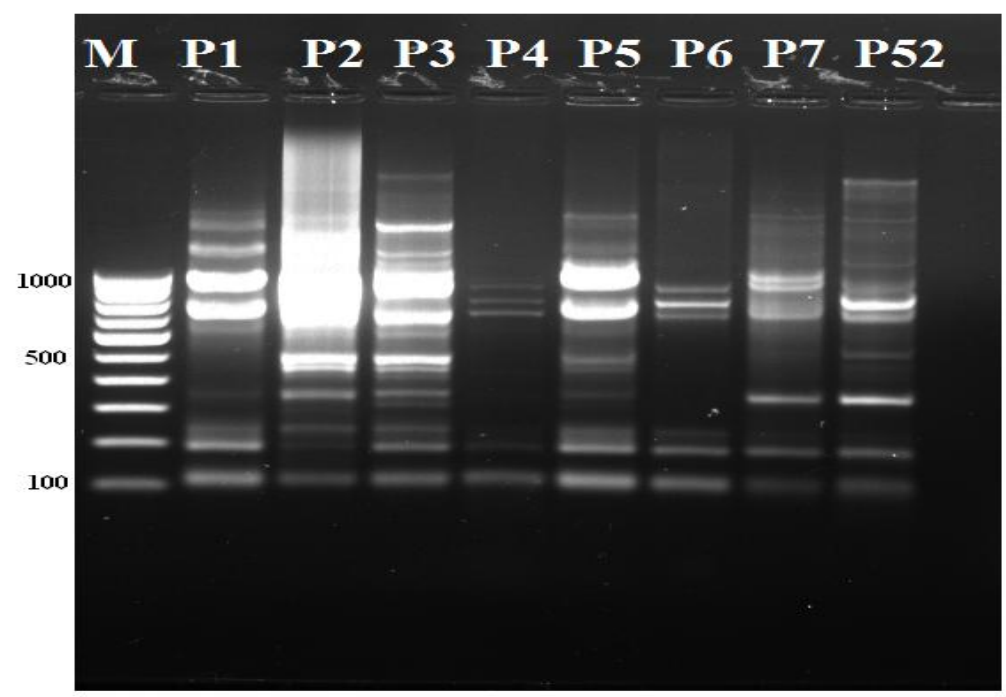

Figure 3. REP PCR profiles. Lanes: M: Marker, 100 bp ladder; P1: isolate $\mathrm{P1}$; P2: isolate P2; P3: isolate P3; P4: isolate P4; P5: isolate P5; P6: isolate P6 $\mathbf{P 7}$ : isolate $\mathbf{P} 7$; P52: Vaccine strain.

Fig.4 Dendogram of isolates of P. multocida based on combined ERIC and REP profiles.

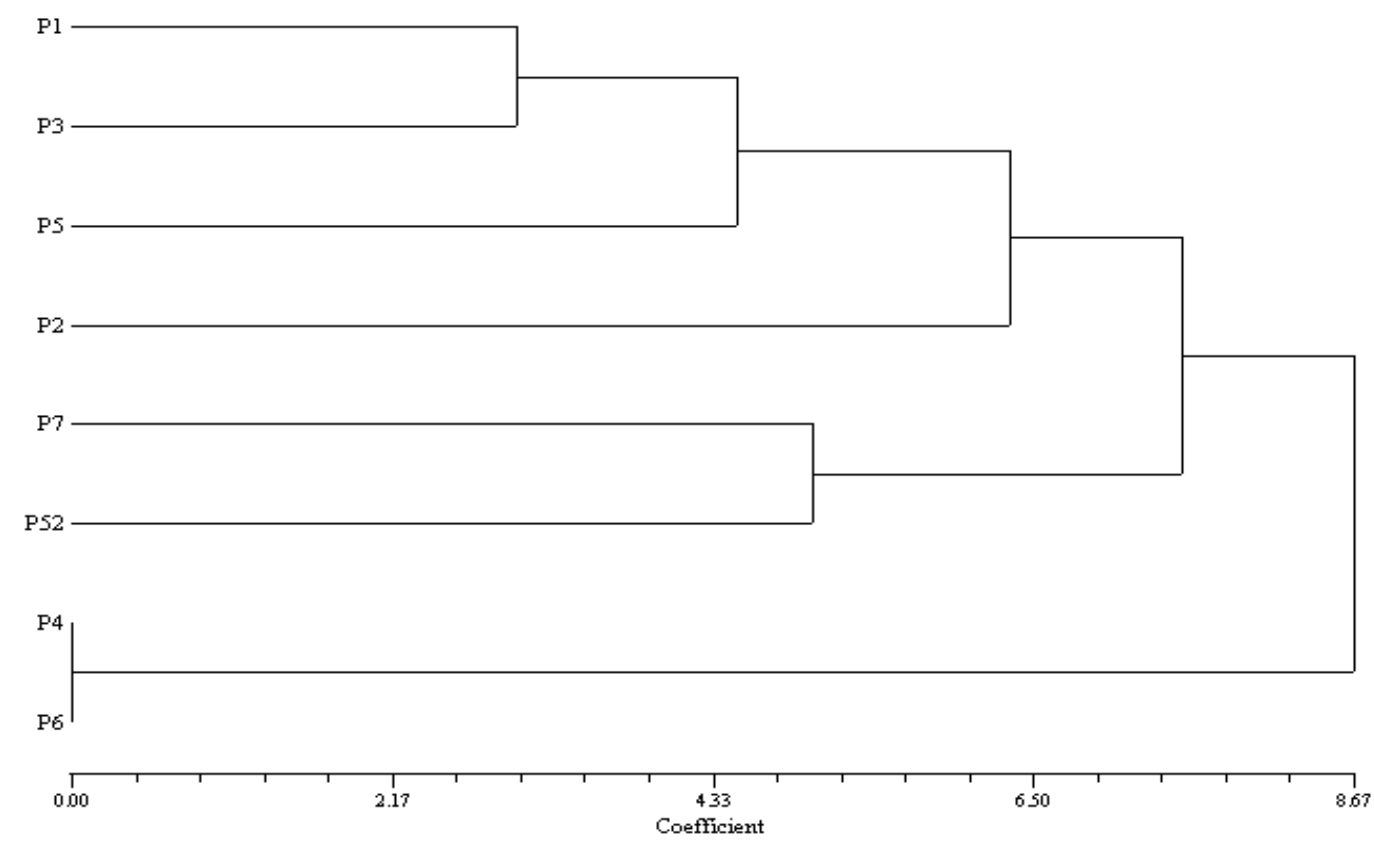

The HSB-PCR method simplifies characterization of type $B$ isolates by detecting all three HS associated serotypes in a single process. The versatility of this assay will enable the technique to be used for routine diagnosis in countries not currently able to perform conventional methods (Saxena et al., 2002). In present study molecular methods were found to be of more efficient than conventional methods.

In combined molecular typing using data produced by ERIC and REP PCR D value of 0.95 was obtained. 
Our findings indicate that in outbreak the isolates which were involved, were from different origin and genetic makeup. In dendogram it can visualized that the isolates of one location are more closely related. Similar findings have been reported from India (Biswas et al., 2004) and other countries (Gunuwardana et al., 2000) (Towensend et al., 1997).

Generally, oil adjuvant vaccine or alumprecipitated and aluminium hydroxide gel vaccines with a vaccine strain of $P$. multocida (P52) are currently used in India for control of HS. The variation at molecular level in the field isolates, in comparison to the vaccine strain, warrants an imminent strategy for controlling HS.

In conclusion, we have shown H.S. is still an important disease spreading in rainy season. PCR based screening can be used effectively for detection of HS-associated serotypes of P. multocida (B:2, B:5 or B:2,5). The present investigation indicates that genetic variation of isolates of same or different origin can be visualized by ERIC and REPPCR.

\section{References}

Biswas, A., S.B. Shivchandra, M.K. Saxena, A. Kumar, V.P. Singh, and Srivastava, S.K. 2004. Molecular variability among the strains of Pasteurella multocida solated from an outbreak of haemorrhagic septicaemia in India. Vet. Res. Commu., 28: 287-298.

Carter, G.R. and Subronto, P. 1973. Identification of type $\mathrm{D}$ strains of $P$. multocida with acriflavin. American $J$. Vet. Res., 34: 293-294.

Gunawardana, G.A., K.M. Townsend and Frost, A.J. 2000. Molecular characterization of avian Pasteurella multocida isolates from Australia and
Vietnam by REP-PCR and PFGE. Vet. Microbiol., 72: 97-109.

Khera, S.S. 1979. The incidence and distribution of epizootic diseases in India: hemorrhagic septicemia. Bulletin of office International des Epizootics. 91 : 331-347.

Loubinoux, J., C. Lion, D. Grain, M. Weba, and Faou, L.E. 1998. Value of ERICPCR for study of Pasteurella multocida strains isolated from mouth of dogs. J. Clin. Microbiol., 37: 24882492.

Naggapa, K., S.P. Singh, S. Tamuly, and Saxena, M.K. 2007. Isolation of Salmonella.

Saxena, M.K., V.P. Singh, A.A. Kumar, P. Choudhuri, V.P. Singh, S.B. Shivachandra, A. Biswas and Sharma, B. 2006. REP-PCR analysis of $P$. multocida isolates from wild and domestic animals in India. Vet. Res. Coтmu., 30: 851-861.

Saxena, M.K., V.P. Singh, B.D. Lakhchura, A. Saxena and Shrama, B. 2004. Detection of virulence in Indian Isolates of Salmonella by Polymerase Chain Reaction. Indian J. Biotechnol., 3: 37-40.

Shivachandra, S.B., A.A. Kumar, R. Gautam, S. Joseph, P. Chaudhuri, M.K. Saxena and Srivastav, S.K. 2004. Detection of Pasteurella multocida in experimental infected embryonated chicken eggs by PCR assay. Indian J. Experimental Biol., 44: 321-324.

Shivshankara, N., M.K. Saxena and Singh V.P.2001. Rapid diagnosis of hemorrhagic septicemia by PCR assay. Indian Vet. J., 78: 101-103.

Townsend, K.M., H.J. Dawkins, and Papadimitriou, J.M. 1997. REP PCR analysis of Pasteurella multocida isolates that cause hemorrhagic septicemia. Res. Vet. Sci., 63: 151-155.

Townsend, K.M., A.J. Frost, C.W. Lee, J. 
M. Papadimitriou, and Dawkins,. H. J. 1998. Development of polymerase chain reaction (PCR) assays for species and type-specific identification of P. multocida. J. Clin. Microbiol., 36: 1096-1100.

Typhimurium from poultry eggs and meat of Tarai region of Uttranchal. Indian J. Biotechnol., 6: 407-408.

Versalovic, J., T. Koeuth, and Lupski, J.R. 1991. Distribution of repetitive DNA sequences in eubacteria and application of fingerprinting of bacterial genomes. Nucleic Acid Res.,
19: 6823-6831.

Wilson, K. 1987. Preparation of genomic DNA from bacteria. In: F.M. Ausabel, R.Brent, R.E. Kingston, D. D. Moore, J.G. Seidman, J.A. Smith and k. Struhl (ads). Current Protocols in Molecular Biology. unit, 2.4.1,(Wiley, New York)

Yoshimura, H., M.Ishmaru, Y. S Endoh and Kojima, A. 2001. Antimicrobial susceptibility of $P$. multocida isolated from cattle and pigs. J. Vet. Med. Infect. Dis. Vet. Public Health, 48: 555-560.

\section{How to cite this article:}

Archana Yadav, Anita Sharma, Rajesh Kumar, V.D.P. Rao and M.K. Saxena. 2016. Molecular Characterization Indian Isolates of Pasteurella multocida Isolated from Buffalo and Cattle in India. Int.J.Curr.Microbiol.App.Sci. 5(9): 302-310. doi: http://dx.doi.org/10.20546/ijcmas.2016.509.034 